\title{
MIGRATION THROUGH A LINGUISTIC EDUCATION PROCESS
}

\author{
Natalia Kirirllova ${ }^{1 *}$, Elena Zaytseva ${ }^{2,}$ Lilia Metelkova $^{3}$, Tatyana Guryanova ${ }^{4}$, OIga \\ Zarubkina $^{5}$
}

\author{
${ }^{1}$ Assoc.Prof, Ms., The Ulianov Chuvash State University, RUSSIA, natkir71@rambler.ru \\ ${ }^{2}$ Assoc.Prof, MS., The Ulianov Chuvash State University, RUSSIA, 917elena@email.ru \\ ${ }^{3}$ Assoc.Prof, Ms., The Yakovlev Chuvash Ctate Pedagogical University) RUSSIA, \\ lakhrt6@gmail.com \\ ${ }^{4}$ Assoc.Prof, Ms., The Ulianov Chuvash State University, RUSSIA, vgurtat@yandex.ru \\ ${ }^{5}$ Assoc.Prof, Ms., St. Petersburg State University of Industrial Technology and Design, \\ RUSSIA, zovru77@mail.ru \\ ${ }^{*}$ Corresponding Author
}

\begin{abstract}
The article is the author's take on the psychological and linguistic side of a migration process. Migration is always stressful, the process of social adaptation is directly related to linguistic and psycholinguistic adaptation. The language factor has become a defining feature of those who migrate to America. Migration is a typical example of how the natural bilingualism functions. A characteristic feature of American attitude to migrants is the manifestation of their positive assessment through a negative description of opposite phenomena: nationalism, especially private nationalism of politicians, and terrorism, extremism, which is proved by the examples taken from the today-American media (The New York Times and Washington Post papers). The linguistic status of migrants may be described as that of people with a multilingual and multicultural identity, living under legal and social constraints, contradictions and very often also facing economic problems. It is a generally accepted view that the ability to speak the language of the receiving society usually plays an important part in the process of integration, because it is a precondition for assimilation. However, it is a necessary, but not a sufficient condition. It seems to be obvious that questions of language therefore can neither be observed and analysed nor be treated in isolation, because all these dimensions and factors are interrelated.
\end{abstract}

The authors conclude that the migration process is both lingual and psychological problem of acculturation of migrants, which occurs in contact with a foreign culture and language.

Keywords: "migration", "multiculturalism", "tolerance", "bilingualism", "cultural shock", "language learning", "adaptation

\section{INTRODUCTION}

The world is changing rapidly under the influence of globalization. The modern world is multi-faceted and contradictory, with both centripetal and centrifugal forces in it. On the one hand, there is a strengthening of 
political, economic and cultural ties between countries, an increase in the volume and speed of information flows, and on the other hand, owing to the growth of national consciousness, new independent states are being formed. In other words, the current situation in the world can be characterized through two opposing trends: the desire of highly developed countries to integrate, spread their cultural, political, and economic values throughout the world, i.e., to globalization; and the resistance of the "other" world to this onslaught, as a reaction to pressure from the "outside", the development of the anti-globalist movement. Not only do people migrate, but also customs, traditions, lifestyles, and languages. The paradox of modernity is that through the Internet, through this world wide web, languages mostly migrate earlier than people. Migration as a phenomenon is always associated with such psychological factors as anxiety, mental tension, fear, aggression, sometimes - apathy, and inadequate self-esteem. Those who find themselves in a new society must adapt to the peculiarities of the functioning of this society, accept new laws and rules, sometimes it is also necessary to change or adjust their own social roles. To some extent, migration is always stressful, the depth of this stress depending on the specific situation. In turn, the process of social adaptation is directly related to linguistic and psycholinguistic adaptation. The migrant must integrate not only into the social and economic life of society, but also into its culture and language.

\section{MAIN STUDY}

One of the important factors of migration is the problem of bilingualism. It should be noted that the formation and development of bilingualism in migration conditions is influenced by extralinguistic factors, the external environment and social factors, but at the same time is significantly determined by the motivation and personal intentions of the migrant. Over the last two decades of the twentieth century, the language factor has become a defining feature of American identity. And of course, when studying migration problems, we can not ignore the fact that the planet has historically long had a number of more or less stable territorial and cultural civilizations that have common religious roots. V. Shubart identifies four cultural and historical civilizations.

1. The Western Catholic Church created artificial space through the bourgeois developed market and with the help of industrial and post-industrial technology. Such a civilization started and marched with a sword and a cross. Its ideal is the human conqueror, but more and more the human consumer. It seeks spreading the values of a society of consumption to the entire planet. Through the international monetary Fund, the World Bank, the WTO, and the Internet, Western ideals and the American way of life is forcibly imposed. Therefore, the statement of former President B. Clinton that "globalization is America" (2: 50) is not a hyperbole. The loss of universal moral guidelines is the prospect of this civilization.

2. The Confucian-Buddhist civilization considers a harmonious person to be its ideal. A person who strives, first of all, for internal harmony, for the optimal balance of society, the state and the individual. He is against violence, he is for a flexible combination of politics and morality. It is significant that Japanese Buddhism largely adopted the moral principles of Confucianism: hard work, thrift, hoarding, worship of elders, devotion to the state, paternalism - bringing asceticism from Buddhism. For this civilization, Confucianism is not so much a religion but a set of immutable ethical laws, a moral code. The vocabulary of a harmonious person does not include such notion as "violence".

3. The Indo-Buddhist civilization formed an ascetic man who goes from the world of things to the inner world of spiritual contemplation; he considers his being on Earth as a temporary stay without hope and without a desire to improve earthly life. An ascetic person has no fear of death. Indo-Buddhist civilization grew out of trust in God. Intrareligious pluralism is its strongest argument for migration of people and ideas. Spiritual tolerance, nonviolent actions - that's what makes it so attractive. 4. In the Orthodox-Slavic civilization, there is a man - the Messiah, the Messianic man. A person who feels the calling to combine the creation of the inner harmony with the outer one. The divine exalted image that he feels in himself, sometimes without realizing it, he wants to bring it about in the world around him. For him, "all men are brothers." Power is not his goal, but, nevertheless, he is ready to reconcile the irreconcilable: power and morality. The Messianic aim is the need to improve the surrounding world in unity with the improvement of the person himself, with his refinement.

I. A. Vasilenko complements the concept of V. Shubart by considering the Islamic-cultural civilization (6: 86) with the man of Islam as primarily an Imperial man. Without interfering into the cosmic harmony, a person nevertheless seeks to assert himself through the strengthening of the state in the form of a military camp. The conquest is his destiny, but it shall be in the form of "Holy" wars. A distinctive feature of the Islamiccultural man is religious intolerance. In our view, all the above mentioned civilizations interact in the modern American society. Migration of people, ideas, beliefs, and lifestyles seldom takes place peacefully. Therefore, in the future, the United States will face great difficulties. Migration is a typical example of how the 
natural bilingualism functions. According to Sadokhin A. P., the process of adaptation of a migrant has several steps: "honeymoon", frustration, "cultural shock', optimism, adaptation (5:125).

International migration in the modern world can be characterized as a large-scale process, but causing both pronounced national and ethnic characteristics, as well as ethno-cultural differentiation, and, as a result, increased intercultural, inter-ethnic and interracial interaction. In particular, massive immigration processes from Latin American countries pose a challenge for the United States to integrate Latinos into American society. So, Hispanics have already surpassed the number of African-Americans, becoming the largest minority in the United States. Spanish is the second most common language in the United States after English. The total number of Spanish-speaking people in this country is second only in absolute numbers to the population of Mexico. Most of government agencies (such as the White House, the Government, National libraries, etc.) maintain records and create websites in two languages (English and Spanish). In the educational institutions, Spanish is the second most popular language (after English), and about $60 \%$ of students choose it as a foreign language. The U.S. census Bureau estimates that the number of Spanish language learners reaches $7,820,000$, of which $3,600,000$ are in elementary school, 3,220,000 are in secondary school, and 1,000,000 are in high school. These changes are very important for the American political system, because they can lead to changes in the voting results, redistribution of social benefits among certain groups of the population, and reorientation of foreign policy. Most immigrants from Latin America conserve their linguistic identity and form ethno-territorial clusters. As noted by $\mathrm{S}$. Huntington, the crucial role of a language for the country was determined even before the emergence of the United States, however, until recently, attempts have been made and are being made to diminish its importance. The "battle for English" is actually one of the fronts of the war for American identity, that is, on this front, it is decided "whether the United States will remain the country of the English-speaking majority or turn into a multilanguage society." In fact, we are not talking about multi -, but about bilingualism (4: 248-249). From 1980 to 2002, twelve "language" referendums were held in three cities and four States. All of these referendums were initiated by the group in defense of the English language. In all but one of the people voted for the English language and against bilingual education. In all cases, the ruling circles actively interfered with their conduct, as did the leaders of Spanish-speaking communities and other linguistic minorities. During this time, activists fighting for the abolition of bilingual education suffered a single defeat - in 2002 in Colorado, where an initiative to abolish bilingual education was blocked by 56 percent of the vote to 44 percent. This result was provided by millionaires who supported the bilingual education system (4: 249). Hispanics in the United States were all the more likely to oppose initiatives on the official status of the English language and supported the policy of bilingualism. The process of hispanization of the American Southwest, the so-called peaceful Reconquista of the lands that the United States took from Mexico in the mid-nineteenth century, is proceeding at a rapid pace. Hispanics today make up $28 \%$ of the population of Texas, $31 \%$ of the population of California. In its history, the United States has never experienced such a mass concentration of members of a single ethnic group. Especially since this ethnic group has a constant contact, being in the immediate vicinity of Mexico. The continued growth of the Hispanic population in the United States and their increasing influence has led to a change in their goals, which they now openly announce. The first is to prevent the assimilation of Spanish-speaking immigrants and their integration into Anglo-Protestant society. Instead, it is proposed to create an Autonomous Spanish-speaking socio-cultural community. Supporters of "Latino" do not recognize the concept of a single national society, attack the idea of a homogeneous cultural community and define the desire to recognize the English language as a national one as a manifestation of xenophobia and chauvinism. "They also attack multiculturalism and pluralism, since these concepts reduce the "diversity of cultural identities" to a "private level" and allow that "in the public sphere, except for special cases requiring ethnic identification, we must abandon national identities and perceive ourselves neutrally as "Americans"." Hispanics should not be associated with American identity; on the contrary, they should "support the nascent "Latin" identity, political and social consciousness of the Latino." Hispanic residents of the United States should demand (and already do!) a separate "cultural citizenship", which implies a "special social space for Latinos" (4). Another goal of Latino is to transform the United States from a society of one culture and one language to a society of two languages and two cultures. Proponents of "hispanization" believe that America as a society with a core Anglo-Protestant culture and many ethnic subcultures has outlived itself, and, in their opinion, it is time for the existence of two equal cultures - Latin (Spanishspeaking) and English. National linguistic identity is being redefined. And the main source of this process is the continuous mass influx of Mexican immigrants. American society is used to talking about immigration and assimilation, and it tends to perceive immigrants as a whole without making any distinction between them. In doing so, it seems to alienate itself from the special features that are inherent in Spanish speaking, primarily Mexican, immigrants, as well as the problems and challenges that arise in connection with this immigration. By sidestepping this problem (or delaying this solution for an indefinite time), as well as considering the issue 
of relations with Mexico in line with normal international policy, the United States is creating its own metamorphosis and trying to deprive itself of the status of a country with a single national language and a core Anglo-Protestant culture. In addition, by being dismissive of this problem, Americans give Hispanic immigrants real hope, which makes the emergence of a society with two languages and two cultures a possible reality. Bilingual education has long been Spanish-speaking. The increased need for Spanish teachers is forcing Puerto Ricans to work in schools. $65 \%$ of children who attend bilingual schools in New York go to Spanish schools because they do not feel the need to learn and use English. Many children study in bilingual schools for at least nine years, which leads to inability to speak English by these students. Many of these children spend their lives in a Spanish-speaking environment: they speak their native language at home, watch TV programs in Spanish, see doctors who speak Spanish, and when shopping sellers also communicate with them mostly in their native language. And only when they grow up, they suddenly realize that their lack of knowledge of the English language does not meet the needs of the profession market. The term "bilingual education" has become a politically correct expression for Spanish-language education. Children of previous generations of immigrants learned English relatively quickly and integrated into American culture, since there were no such educational programs at that time. Children of today's nonHispanic immigrants also quickly learn English and assimilate with American society quite easily. The leaders of the Spanish-speaking community aim to equalize the rights of the Spanish language with English. But the desire for bilingualism as a standard of living is supported not only by the Spanish-speaking community. Individual liberal and legal organizations, leaders of faiths (primarily Catholic, which is acquiring an increasing number of new parishioners from among Latin American immigration), as well as politicians, both Republicans and Democrats, talk about the need for a bilingual system. In addition, it should also take into account the interests of businesses focused on the Spanish language market, which resists the official status of the English language, fearing to lose their multimillion consumers. American business is also targeting the Hispanic community. Supermarket owners in many cities of the country select a range of products; hire a staff of sellers, taking into consideration the needs of the Spanish-speaking population. Ads, advertisements, and pointers are increasingly appearing in the bilingual version. Bilingualism has also begun to influence income levels, for example, bilingual police and firefighters in cities in the South-West receive more than their counterparts who can speak only English. In disputes over language policy, Senator S. I. Haiyakawa, who in 1981 initiated the discussion of a constitutional amendment declaring English the official language, described the unique situation of Spanish-speaking immigrants regarding their stay in the English language environment as follows: "Why do neither Filipinos nor Koreans object to the recognition of English as the official language of the country? Why don't the Japanese mind, much less the Vietnamese? They learn English as quickly as they can, and often win prizes in various competitions. But Hispanics is a serious problem. They are actively involved in the struggle to grant Spanish the status of the second official language of the United States" (3). Another phenomenon should be taken into account when dealing with global migration processes. Today, civilized people complain that the modern languages are becoming meager, and young people speak some primitive slang, and writers fail to so light up the "the hearts of people" with their works of art. However, is this true? Scientists were able to adapt the famous Google search service to conduct unprecedented linguistic research. 5 million 200 thousand digitized books were taken, written in English, 144 French, Spanish, German, Chinese and Russian over the past 200 years. And then, using special programs, they compiled a database of words used in them (about five hundred billion), and then conducted an analysis. And it turned out that over the past hundred years, the number of words we use has doubled - from five hundred and forty-four thousand in 1990 to one million in 2000. At the same time, most of the new words have entered the human vocabulary over the past fifty years. Thus, the considerations that the human language has become poor are greatly exaggerated, at least, when it comes to languages spoken by half of the world's population (4). This is also the result of a deepening and expanding migration.

Most Americans, however, resist the policy of bilingualism, remaining supporters of one language. For them, English remains the most important symbol of national identity. But despite this, the Spanish language is gradually being equalized with the language of the country's Founding Fathers. If this trend does not change, the cultural disparity between Spanish-speaking and English-speaking America will replace the racial divide between the descendants of Anglo-Saxons and Africans in American society. A bilingual and bicultural America will be completely different from an America with a single language and a core Anglo-Protestant culture. As noted by S. Huntington, by the time President Clinton in 1997 declared the need for a third "great revolution" in America to prove that it could exist without a dominant European culture, this revolution had lasted for several decades. The multiculturalist movement for the rejection of Anglo-Protestant culture and for the assertion of "diversity of cultures", which arose in the 70s of the XX century, achieved significant success in the 80 's and early 90's, and then faced serious opposition in the "culture wars". Today, at the 
twenty-first century, it is not yet clear whether this revolution has been fully realized. Talks about bilinguals, migrants and multiculturalism as a whole start in a society when there is an identity crisis, when something that was considered fixed and stable is replaced by doubt and uncertainty (1). Then follows the consideration of identity not as self-sufficiency, but as openness to other cultures, which is why multiculturalism is considered primarily against the background of such a phenomenon as migration. There is no doubt that migration in the modern world is understood both positively as cultural exchange and negatively as a threat. A characteristic feature of American attitude to migrants is the manifestation of their positive assessment through a negative description of opposite phenomena: nationalism, especially private nationalism of politicians, and terrorism, extremism, which is proved by the following examples taken from the todayAmerican media. The American media are quick to react to the migration process thus being the so-called mirror of migration where migration is described and the reaction of the American society is presented. Teaching a foreign language is based on the synthesis of knowledge from psycholinguistics, pedagogy, and sociology. In the classroom, the teacher should not forget there are deeply different civilizations and cultures that represent not only different visions of the world, but also different worlds in themselves. Will these worlds be able to understand each other, or will each civilization remain impenetrable to others? Such a question, which can be referred to by the word "tolerance" is widely used today, finding its solution when studying English language. Using texts on migration from English-language press contributes to the formation of the tolerant personality of students studying at the faculty of foreign languages.

1. What does it mean for the president of the United States to proclaim that he is a "nationalist"?... The word "nationalism" in modern America has often been preceded by a troubling adjective: "white." Troubling, that is, if you believe in America as a multicultural democracy bound together by shared ideals, not by shared blood (Washington Post 25.10.18. Donald Trump embraces 'nationalism' of the worst kind).

2. President Trump's order allowing state and local officials to veto refugee resettlement in their communities is likely "unlawful," the judge said. In Texas, Lina Hidalgo, the top executive for Harris County, the largest county in the state and home to Houston, had opposed Governor Abbott's veto and hailed the judge's ruling. "Our region, a top destination for refugees in the world, is proof that welcoming refugees contributes to economic success and strong, safe communities," she said. "Opening our doors to those who are most in need should transcend partisan politics." Mark Hetfield, president of HIAS, the Jewish refugee resettlement agency, noted that a majority of governors and municipalities had already expressed a desire to continue welcoming refugees. "To those few who have not," he said, "we say not only is it unkind and un-American to ban refugees from your states and towns, but it is unlawful." (New York Times 15.01.2020).

3. European populists continue to flog the narrative that migrants are invading, even though the European Union's migration policy has starkly reduced the number of new arrivals... But the bloc's approach has been sharply criticized by humanitarian and refugee-rights groups (New York Times 9.09.2019).

4. Restaurants, farms and other businesses say they need more foreign workers. And economic growth may depend on it, given lower birthrates (New York Times 23.08.2019. Is Immigration at Its Limit? Not for Employers).

The discursive practices of opponents of migration are reduced to the meaning of "threat", first of all, the threat from immigrant refugees, who are described as a man or woman with no choice due to the specific conditions of escape. Such conditions may be explicitly "political" - concerning reprisals against specific parties, organizations or individuals, ethnic, "racial" or religious groups, or persons of a certain sexual orientation. Equally, the causal factors may be economic - wars, landlessness, famine, or environmental collapse.

6. ...Guatemala is itself one of the most dangerous countries in the world. "These are bad people," Mr. Trump told. Mr. Trump has frequently told his advisers that he sees the border situation as evidence of a failure to make good on his campaign promise to seal the border from dangerous immigrants. (New York Times 26.07.2019).

7. More pressing threats _ _..risk of illegal migrant flows from Libya and sub-Saharan Africa - mean that Europe is unlikely to seriously heed the president's wishes (WP 10.01.2020). Today, white supremacy is increasingly centered on the perceived victimhood of whites, left defenseless in a multicultural world of widespread immigration, affirmative action and interracial marriage (Washington Post 31.10.18. Saviors of the white race...).

8. European culture is under threat from multiculturalism and migration, has long vilified the liberal... (Washington Post 26.10.18). 
Along with the religious and cultural threat the discourses express the risk of destruction of national identity and social cohesion:

9. Although we have a policy of multiculturalism, for most Canadians there is an expectation that immigrants will conform to the mainstream," said Jeffrey Reitz, the director of the Ethnic, Immigration and Pluralism Studies program at the University of Toronto " (New York Times 25.06.17 A Battle Over Prayer in Schools Tests Canada's Multiculturalism).

10. That is the case in most of Canada, which trumpets multiculturalism like a national anthem. But Quebec, the only French-majority province in an Anglophone country, has always been different, never quite signing onto the idea of multiculturalism, which was viewed from the outset as another way for English Canada to devalue Quebec's culture and place in the country (New York Times 25.10.17. Behind Quebec's Ban on Face Coverings, a Debate Over Identity).

These examples show the attitude of ordinary citizens and representatives of state power.

Multiculturalism as a part of American politics, culture, and life in general is only positively represented in the American media. The above examples show the migration process is both lingual and psychological problem of acculturation of migrants, which occurs in contact with a foreign culture and language. A migrant gets familiar with new artistic values, social and material creations, the actions of people that depend on perceptions of values, norms and conventions, modes of thinking peculiar to a foreign culture. But often contact with a foreign culture leads to such a problem and conflicts associated with a lack of understanding of this culture, which is now called cultural shock (transition shock, cultural fatigue). The main cause of cultural shock in the process of intercultural adaptation is the difference of cultures. Symptoms of cultural shock can range from exaggerated concerns about the quality of water and food to psychosomatic disorders. But cultural shock has not only negative consequences. Modern researchers consider it as a normal reaction, as part of the process of adaptation to new conditions. Moreover, during this process, the person does not only acquire knowledge about the new culture and about the norms of behavior in it, but also becomes more culturally developed, although he experiences stress. The adaptation process is also influenced by the culture to which migrants belong. Thus, the answer to the question of solving the urgent problem of overcoming difficulties in the process of intercultural adaptation by representatives of different peoples is that the migrant must learn the language of the host country in inseparable unity with the world and culture of the people who speak this language. Overcoming the language barrier and cultural differences are effective factors in ensuring mutual understanding between representatives of different ethnic groups.

\section{REFERENCE LIST}

1. Favell, A. (2001). Philosophies of Integration: Immigration and the Idea of Citizenship in France and Britain, 2nd edition. Migration, minorities, and citizenship. Basingstoke: Palgrave in association with Centre for Research in Ethnic Relations University of Warwick. 288 p.

2. Freedman, J. (2004). Secularism as a Barrier to Integration? The French Dilemma. International Migration. 42(3). URL: https://eprints.soton.ac.uk/id/eprint/34033.

3. Haiyakawa, S. (1992) quoted in James Crawford, Hold Your Tongue: Bilingualism and the Politics of «English Only». Reading, MA: Addison-Wesley, p. $149-50$.

4. Huntington, S.(2008). Who are we? Moscow: ACT.

5. Sadokhin, A. P. (2003). Intercultural communication: A textbook. Moscow: Alpha-M.; Infra-M, 288 p.

6. Vasilenko, I. A. (2003). Political globalization.Moscow, Logos.

7. Zaytseva, E.L. (2014). Evaluative characteristics of mass media discourses: comparative aspect. Linguistics, Lingvodidaktika, Theory of Translation: topical issues and prospects of a research materials of the international scientific and practical conference. I.B. Getskina (editor-in-chief). P. 3237.

8. Prokoshenkova, L. P., Zaytseva, E.L. (2014). Negative evaluative semantics as a factor of formation of ethnic self-consciousness (on materials of English-language political texts). Modern Problems of Science and Education. 6, P. 1261. 